Names, Vol. 32, No. 4 (December 1984)

\title{
The Pilot Training Course in Toponymy in Indonesia
}

\section{F. J. ORMELING}

\section{Introduction}

$\mathrm{T}$

he value of establishing training courses in toponymy, with particular emphasis on field collection and office treatment of names, has been expressed repeatedly by UN Regional Cartographic Conferences, by UN Conferences on the Standardization of Geographical Names as well as by the UN Group of Experts on Geographical Names (UNGEGN). Since aerial photographs and satellite imagery reveal no geographical names, a new type of specialist - the name collector - must go into the field to acquire and check them, after which the collected names are processed in the office by other specialists.

Participants at the third session of the UNGEGN in New York in 1971, under the chairmanship of Dr. Meredith F. Burrill, noted the worldwide interest in field collection and office treatment of geographical names for mapping and other purposes. At the same time, they recognized that the number of persons with some basic knowledge and experience in geographic nomenclature was far from adequate, particularly in developing countries where more than one language may be spoken and where languages may lack writing systems.

It was agreed that special courses were needed to bring out and emphasize the importance, problems, and procedures of field collection and office treatment of names. These courses should be attended primarily by senior officers involved in mapping who subsequently would be able to train and supervise junior staff in their respective countries. At this stage of discussion, Dr. Burrill introduced the concept of a pilot training course in order to collect experience. From the outset, it was clear that such an experiment would serve its purpose only when followed by subsequent courses of a more permanent nature.

\section{Establishment of a Working Group on Training Courses}

In 1972, the second UN Conference on the Standardization of Geo- 
graphical Names in London adopted a resolution recommending international and national authorities to give maximum support to training courses in the collection and treatment of names. On the basis of that resolution, during the fifth session of the UNGEGN in 1973, a Working Group on Training Courses was established with a specific task - develop the organization and program of such an experimental training course. The start of the Working Group was most promising. Members soon reached agreement on the general outline of a course, its duration and program, the level of its students, and the requirements of its lecturers.

As far as the program was concerned, the Working Group recommended a series of basic lectures on the following subjects: (1) global distribution of languages and scripts; (2) functions of geographical names; (3) UN activities on standardization of geographical names; (4) general problems of national authorities in names; (5) writing systems and their converse, nonwritten languages; (6) general problems of field collection, concentrating on specific problems in the host area; (7) office treatment of names; (8) exonyms; (9) generics and glossaries; and (10) national gazetteers.

The Working Group further recommended that the lectures be followed by exercises in practical field collection, by excursions to libraries and cartographic institutions, and last, by a critical appraisal of the course by both lecturers and students. Participating students should be at the university level and have some linguistic skill and field experience in geographical names. Lecturers should be recruited from the 14 major linguisticgeographic divisions which then comprised the UNGEGN. Preference should be given, however, to members of the UNGEGN who are familiar with the UN names standardization policy and to experts of the host area. Finally, the Working Group strongly recommended that the UN cosponsor the training course and provide funding.

\section{Failure of First Attempt}

Given agreement on the basic principles of a pilot training course, the inevitable conclusion was to organize one. In 1973, the UNGEGN mandated the Working Group to take the next steps, i.e., to find a host country willing to cosponsor the course, to compose a team of international experts to serve as lecturers, and to investigate the possibilities of followup courses.

In 1974, the Institute for Aerial Survey and Earth Sciences (ITC) in Enschede, The Netherlands, offered to host a pilot course along the lines stipulated by the UN Working Group. In 1975, the government of The 
Netherlands offered to finance round-trip travel and accommodations for 25 to 30 students from English-speaking countries in Africa and Asia to Enschede if the similar expenses for the lecturers would be met by other bodies, preferably by the UN. When no financial assistance was forthcoming, the government of The Netherlands withdrew its offer and plans for the training course in Enschede in 1976 were cancelled.

\section{New Prospects in Indonesia}

In 1979, a new host country presented itself. It was Indonesia, involved at that time in an impressive mapping program and, as such, fully sensitized to the importance of geographical names standardization for mapping. At the eighth session of the UNGEGN in 1979, Professor J. Rais of Indonesia announced that his country would be willing to host the first, "experimental" training course.

In preparing the course, the Indonesian National Coordinating Agency for Surveys and Mapping (Bakosurtanal), under Chairman Pranoto Asmoro, took care of the local organization, including accommodations for participants, transport, classroom facilities, technical visits, and field work.

The recruitment of international lecturers, the course program, and the timetable became the responsibility of the UNGEGN Working Group. With the exception of a brief visit to Jakarta by the convenor of the Working Group in September 1981, all contacts were conducted by correspondence. Further, the convenor worked in close contact with Mr. M. de Henseler, chief of the UN Cartography Section, New York, and with Dr. J. Breu, Vienna, who had succeeded Dr. Burrill as chairman of UNGEGN in 1977.

Through the office of UN Undersecretary Bin Jilong, letters were sent to member states inviting them to send lecturers to the training course. In this way, the UN, under whose sponsorship the concept of training courses was originally developed, provided important "moral" support. Since the course was primarily intended for participants from the UNGEGN Division Asia SE and Pacific SW, invitations to participate were primarily sent out by the host country, in cooperation with the convenor of the Working Group, to countries of that Division.

As might be expected, the preparations, which were carried out over the Jakarta-Enschede-New York-Vienna network, suffered delays. Twice the course had to be postponed until finally the second and third weeks of June 1982 were decided upon. 


\section{Overcoming New Obstacles}

The main problem again facing the enterprise was funding, particularly for transportation and subsistence for the lecturers. The problem became even more acute as only a few UN member states responded positively to the UN Undersecretary's invitation to sponsor expert lecturers. It was in this critical phase that the host country, Indonesia, realizing that the collection and processing of geographical names constituted an essential part of mapping, offered financial aid taken from World Bank loans intended for its mapping projects. The course was finally saved when the lecturers, upon suggestion of the convenor of the Working Group, agreed to forego remuneration and daily allowances, and when a favorable rate for board and lodging for the team of lecturers was worked out with a hotel in Cisarua, Indonesia, where the course was to be held.

A last obstacle had to be overcome when Dr. Breu, chairman of UNGEGN and also a keynote lecturer of the course, had to cancel his participation. Fortunately, H. A. G. Lewis, chairman of the Permanent Committee on Geographical Names for British Official Use and member of UNGEGN since its founding, was willing to replace Breu at short notice.

Finally, on 6 June 1982, the following lecturers gathered in Cisarua, a mountain resort (altitude $700 \mathrm{~m}$.) in West Java: (1) R. Böhme (FRG), representative of M. de Henseler, chief of the UN Cartography Section; (2) D. P. Blok (Neth.); (3) E. Földi (Hungary); (4) H. A. G. Lewis (UK); (5) F. J. Ormeling (Neth.); (6) J. Rais (Indonesia); and (7) I. M. Sandy (Indonesia). The first five individuals lectured on one or more topics of the curriculum, while Rais and Sandy dealt with the toponymic problems in Indonesia.

Unexpected and welcome assistance was supplied also by D. T. Pearce (Australia) and A. Taylor (USA) who lectured on the standardization of geographical names in their respective countries. In all, 30 students from various mapping and educational institutions attended the course. Among the participants, in addition to those from the host country, were representatives from Malaysia, Nepal, Philippines, and Thailand. On June 7, the course was officially opened by Pranoto Asmoro of Bakosurtanal.

\section{The Course}

In preparing the course, the organizers followed the program drafted by the UNGEGN Working Group on Training Courses and agreed upon by the sixth UNGEGN session in 1975. The program consisted of two parts: 
(1) a series of lectures serving as an introduction to the complex matter of geographical names standardization; and (2) a series of field trips in the Leuwiliang region west of Cisarua, during which the participants were exposed to actual field collection of names. The area for field work was carefully selected by the Indonesian organizing committee and offered an interesting variety of topographic, hydrographic, and cultural details. Its location in the Sundanese-speaking part of Java presented an extra difficulty that was solved, however, by assigning Indonesians who spoke Sundanese to each field party. The field collection was carried out on the basis of blank topographic sheets at 1:50,000 compiled and printed for the occasion by Bakosurtanal.

In accordance with the recommendations of the UNGEGN, an exhibition was set up to show maps relevant to name problems, gazetteers, and related literature; these were supplied by lecturers and participants. Ample time was set aside for discussion, during which the participants talked about interesting aspects of their national tasks. In the evenings of the second week, participants gathered to summarize and compare the results of their field work. Social and technical tours provided welcome changes in the busy schedule.

\section{Recommendations for the Host Country}

At the closing session of the course, participants and lecturers prepared a written recommendation to Bakosurtanal to promote the establishment of a National Indonesian Names Authority in accordance with the recommendations of the UN Conferences on the Standardization of Geographical Names. The document suggested the members include representatives from Bakosurtanal, the National Language Center, the Ministry of Education and Culture, the Ministry of the Interior, the departments of language and literature of the universities, and from other qualified organizations.

Further, the participants agreed that similar courses in toponymy, particularly in field collection and office treatment of names in Indonesia, would be valuable for geography and cartography students and for staff of the main mapping agencies. Finally, participants recommended that Bakosurtanal promote the introduction of toponymy in the geography/ cartography curriculum at the university level in order to provide regular training opportunities under the guidance of experienced lecturers.

\section{Recommendations for Future Training Courses}

The course was concluded by the presentation of two evaluations: one 
by participants and the other by lecturers. The main points of these evaluations, which showed considerable commonality, are:

1. In general, the program was considered well planned and highly satisfactory. The prevailing opinion was that the course had been successful and served its purpose.

2. The sequence of theoretical subjects recommended by the UNGEGN, preceded by an introduction into toponymic terminology and followed by practical field collection of geographical names, was considered very effective. It was felt, however, that the lecture part of the program did not adequately deal with the linguistic-historic aspects of toponymy, while office treatment did not receive enough attention, due to lack of time. It was recommended that future courses would save valuable time if field work could take place in an area where official mapping is in progress and where facilities for carrying out office treatment of names are available.

3. In view of the importance of names standardization for mapping programs in developing countires, it was generally felt that, in the future, some form of assistance should be provided by the UN, since financial constraints often prevent countries from sending participants. As noted earlier, if the host country, Indonesia, had not provided generous financial assistance, the second attempt to organize a course also would have failed.

4. Accommodations in a bungalow park in the mountains of West Java, away from the distractions of the city, were appreciated by participants and lecturers alike. The joint lunches and tea and coffee breaks stimulated open and excellent exchanges of information and discussion.

5. As to participants of future courses, the group recommended that lecturers and participants include not only specialists from mapping agencies but also experts dealing with other aspects of geographical names such as linguists (two Indonesian linguists attended the course), historians, archeaologists, and anthropologists.

6. Technical visits to the leading Indonesian mapping agencies were considered worthwhile, inspiring, and informative. The group recommended that, in the future, visits also include institutions such as the national archives and national libraries to introduce participants to documentation aspects of geographical names.

7. As far as the field work was concerned, it was agreed that the use of maps at the scale of 1:50,000 might be difficult for those participants not familiar with map reading. Since courses of this nature have students with a mixture of academic and practical backgrounds, the use of larger map scales (e.g., 1:25,000) supplemented by aerial photographs may be recommended.

8. Future training courses should be extended to three weeks, as was proposed by the UNGEGN Working Group. The course in Cisarua was too short, to the detriment of the lecture program.

\section{Conclusion}

The realization of the pilot Training Course in Toponymy must certainly give great satisfaction to Dr. Burrill. During his chairmanship of UNGEGN, he pursued the matter with great perserverance, a quality that he passed on to the members of the Working Group if not to all UNGEGN members. It is even more gratifying to realize that the event generated a series of new activities. Various countries offered to host 
similiar courses. At the time of this writing, a course in Arabic is scheduled to be held in Morocco in 1985 .

Further, various academic institutions in Europe and elsewhere have introduced toponymy into their geography/cartography curricula. It seems that the seeds sown on the banks of the East River in New York in the 1970s have germinated and that the seedlings will prosper and spread. We owe Dr. Burrill a great debt of gratitude. 